\title{
Corrigendum: Early Trauma and Cognitive Functions of Patients With Schizophrenia
}

\section{OPEN ACCESS}

Approved by:

Frontiers Editorial Office,

Frontiers Media SA,

Switzerland

*Correspondence:

Carolina G. Carrilho carolcarrilho1@hotmail.com

André B. Veras

barcielaveras@hotmail.com

Specialty section:

This article was submitted to

Psychopathology,

a section of the journal

Frontiers in Psychiatry

Received: 30 April 2019

Accepted: 13 May 2019

Published: 28 May 2019

Citation:

Carrilho CG, Cougo SS,

Bombassaro T, Varella $A A B$, Alves GS,

Machado S, Murillo-Rodriguez E, Malaspina $D, N$ ardi $A E$ and Veras $A B$

(2019) Corrigendum: Early Trauma and Cognitive Functions of

Patients With Schizophrenia.

Front. Psychiatry 10:377.

doi: 10.3389/fpsyt.2019.00377
Carolina G. Carrilho ${ }^{1 *}$, Simone S. Cougo ${ }^{1}$, Tatiane Bombassaro', André Augusto B. Varella ${ }^{2}$, Gilberto S. Alves ${ }^{3}$, Sergio Machado ${ }^{4,5,6}$, Eric Murillo-Rodriguez ${ }^{5,7}$, Dolores Malaspina $^{8}$, Antonio E. Nardi ${ }^{6}$ and André B. Veras ${ }^{1,5,6,8 *}$

\begin{abstract}
1 Translational Research Group on Mental Health (GPTranSMe), Dom Bosco Catholic University, Campo Grande, Brazil, ${ }^{2}$ Research Laboratory on Autism and Behavior (LAPAC), Dom Bosco Catholic University, Campo Grande, Brazil, ${ }^{3}$ Department of Internal Medicine, Federal University of Maranhão (UFMA), São Luís, Brazil, ${ }^{4}$ Physical Activity Neuroscience Laboratory, Physical Activity Sciences Postgraduate Program-Salgado de Oliveira University (UNIVERSO), São Gonçalo, Brazil, ${ }^{5}$ Intercontinental Neuroscience Research Group, Universidad Anáhuac Mayab, Mérida, Mexico, ${ }^{6}$ Laboratory of Panic and Respiration (LabPR-UFRJ), Psychiatry Institute of Federal University of Rio de Janeiro (IPUB-UFRJ), Rio de Janeiro, Brazil, ${ }^{7}$ Laboratorio de Neurociencias Moleculares e Integrativas, Escuela de Medicina División Ciencias de la Salud, Universidad Anáhuac Mayab, Mérida, Mexico, ${ }^{8}$ Departments of Psychiatry, Neuroscience and Genetics, Icahn School of Medicine at Mt. Sinai Medical Center, New York, NY, United States
\end{abstract}

Keywords: Schizophrenia, cognition, early trauma, memory, attention

\section{A corrigendum on}

Early Trauma and Cognitive Functions of Patients With Schizophrenia

by Carrilho CG, Cougo SS, Bombassaro T, Varella AAB, Alves GS, Machado S, Murillo-Rodriguez E, Malaspina D, Nardi AE and Veras AB (2019). Front. Psychiatry. 10:261. doi: 10.3389/fpsyt.2019.00261

In the original article, there was an error. We did not add an acknowledgement section, which is required in order to acknowledge a financial contribution we recently received.

A correction has therefore been made to the original article and the section ACKNOWLEDGEMENTS has been added:

"Sergio Eduardo de Carvalho Machado, was supported by a grant from the Carlos Chagas Foundation for the Research Support in the State of Rio de Janeiro (FAPERJ), Young Scientists from the State of Rio de Janeiro, E -26/203.295/2017."

The authors apologize for this error and state that this does not change the scientific conclusions of the article in any way. The original article has been updated.

Copyright $\odot 2019$ Carrilho, Cougo, Bombassaro, Varella, Alves, Machado, Murillo-Rodriguez, Malaspina, Nardi and Veras. This is an open-access article distributed under the terms of the Creative Commons Attribution License (CC BY). The use, distribution or reproduction in other forums is permitted, provided the original author(s) and the copyright owner(s) are credited and that the original publication in this journal is cited, in accordance with accepted academic practice. No use, distribution or reproduction is permitted which does not comply with these terms. 